\title{
Efeitos de dois métodos de secagem sobre a qualidade físico-química de grãos de milho safrinha - RS, armazenados por 6 meses
}

\section{Effects of two methods of drying on quality physical and chemical grain winter corn - RS, stored for 6 months}

\author{
Gelson Schuh ${ }^{1}$; Roberto Gottardi²; Edar Ferrari Filho ${ }^{1}$; \\ Luidi Eric Guimarães Antunes ${ }^{1}$; Rafael Gomes Dionello ${ }^{3 *}$
}

\begin{abstract}
Resumo
O objetivo deste trabalho foi avaliar a qualidade físico-química de grãos de milho safrinha, colhidos no mês de julho, no município de Eldorado do Sul, Rio Grande do Sul, submetidos a dois métodos de secagem e armazenados por seis meses a granel. O trabalho foi realizado na EEA da UFRGS em Eldorado do Sul - RS na safra agrícola 2007/2008, os grãos colhidos com umidade de aproximadamente $30 \%$, e posteriormente foram submetidos à secagem em silo secador de concreto armado, através de dois métodos, sendo: 1 . Secagem em leito fixo com ar natural não aquecido, na condição ambiente; 2 . Secagem em leito fixo com ar natural aquecido com GLP. A altura de camada para a secagem foi de um metro em todos os silos. Após a secagem os grãos foram armazenados a granel, nos próprios silos onde foram realizadas as secagens. Posteriormente e em intervalos de 3 meses foram realizadas as seguintes análises físico-químicas: peso de 1000 grãos, peso volumétrico, umidade, proteína bruta, extrato etéreo, cinzas e carboidratos. A secagem dos grãos foi realizada com fluxo de ar de $2,52 \mathrm{~m}^{3} . \mathrm{s}^{-1}$, a temperatura média do ar durante a secagem com ar natural foi de $17^{\circ} \mathrm{C}$ e durante a secagem com ar natural aquecido com GLP foi de $22{ }^{\circ} \mathrm{C}$. O tempo médio de secagem com ar natural foi de 48 horas, enquanto que para a secagem com ar natural aquecido com GLP foi de 34 horas. Os grãos de milho foram colhidos com umidade de $31,88 \%$ e posteriormente secos com ar natural até atingirem umidade de $15,7 \%$ e com ar natural aquecido com GLP até umidade de 13,39\%.
\end{abstract}

Palavras chave: Armazenamento, ar natural, gás liquefeito de petróleo, qualidade

\begin{abstract}
The objective of this study was to evaluate the physical and chemical quality of grains maize, harvested in July, in Eldorado do Sul, Rio Grande do Sul, using two drying methods and stored for six months in bulk. The study was conducted in the EEA of UFRGS, in Eldorado do Sul - RS in the crop year $2007 / 2008$, the harvested grain with humidity of about $30 \%$, and were subsequently subjected to drying in-bin drying of concrete, using two methods, 1 . Stationary drying with natural air is not heated at room temperature, 2. Stationary drying with natural air heated with LPG. The height of layer for drying was one meter in all silos. After drying the grains were stored in bulk in their own silos, where they were drying out. Subsequently, at intervals of 3 months were carried out following physical chemical analysis: 1000 grain weight, volumetric weight, moisture, crude protein, ether extract, ash and carbohydrates. The drying of the grains was conducted with air flow of $2.52 \mathrm{~m}^{3} \cdot \mathrm{s}^{-1}$, the average air temperature during

\footnotetext{
${ }^{1}$ Aluno de mestrado no Programa de Pós-Graduação em Fitotecnia, Faculdade de Agronomia, Universidade Federal do Rio Grande do Sul, UFRGS. E-mail: gelsonschuh@yahoo.com.br; edarff@gmail.com; luidieric.antunes@gmail.com

2 Aluno de graduação bolsista PIBIC, Faculdade de Agronomia, UFRGS. E-mail: r.gottardi@yahoo.com.br

${ }^{3}$ Prof. Adjunto 1, Departamento de Fitossanidade, Faculdade de Agronomia, UFRGS. E-mail: rafdionello@hotmail.com

* Autor para correspondência
} 
drying with natural air was $17{ }^{\circ} \mathrm{C}$, during drying with air natural heated with LPG was $22{ }^{\circ} \mathrm{C}$. The average air drying naturally was 48 hours, while for drying with warm air naturally with LPG was 34 hours. Grains of corn were harvested with moisture content of $31.88 \%$ and then dried with natural air to reach $15.7 \%$ moisture and air heated with natural LPG up 13.39\% moisture. Based on the results we can conclude that: 1 . The drying with natural air heated with LPG was faster than air drying in natural conditions of the study; 2. In conditions of high humidity and low temperature drying with natural air should be performed with care due to the equilibrium moisture content; 3 . The two drying methods are feasible in terms of quality, but the losses of crude protein, lipid and carbohydrates were higher during the first six months of storage in dry grains with natural air; 4 . The natural air drying can be an excellent alternative and low cost to small farmers to dry grain.

Key words: Storage, natural air, liquefied petroleum, quality

\section{Introdução}

O milho é uma planta anual, herbácea, pertencente à classe das monocotiledôneas, família Poaceae, gênero Zea, espécie Zea mays L. (PROGRAMA MULTINSTITUCIONAL DE DIFUSÃO DE TECNOLOGIA EM MILHO DO RS, 1996). O milho é o segundo grão mais produzido no país, perdendo somente para a soja, chegando a aproximadamente 58 milhões de toneladas, na safra 2007/2008, e com produção de aproximadamente 50 milhões de toneladas na safra 2008/2009 (CONAB, 2009).

Perdas quantitativas e qualitativas, de grandeza extremamente variável, ocorrem tanto na colheita como em todas as etapas do sistema pós-colheita, ou seja, no transporte, manuseio, secagem, armazenamento, processamento, comercialização e nos pontos finais de distribuição aos consumidores (ELIAS, 2008). No Brasil perdas nas etapas de pós-colheita de grãos estão entre 25 e $30 \%$ do que é produzido (LORINI; MIIKE; SCUSSEL, 2002) e programas de investimento para a secagem do produto nas regiões de produção e consumo são fundamentais para aumentar a eficiência da comercialização (SARTORI, 2001). De acordo com a FAO (2009), considera-se que perdas da ordem de 10 a $15 \%$ ocorram regularmente nas etapas póscolheita de cereais e leguminosas nos países em desenvolvimento. Em algumas regiões da África e América Latina, estima-se que as perdas possam chegar a $50 \%$ da quantidade colhida.

A secagem de grãos em baixa temperatura, em leito fixo é uma das alternativas de secagem dentro da cadeia de produção. Possibilita a obtenção de um produto final de melhor qualidade, devido à baixa movimentação dos grãos no silo, evitando o dano mecânico que ocorre nos sistemas de secagem que existe movimentação dos grãos e pelo fato do produto não sofrer choques térmicos e hídricos. Além disso, exige um baixo investimento inicial se comparado com os sistemas de secagem que utilizam altas temperaturas (ELIAS, 2008).

Segundo Weber (1998), Portella e Eichelberger (2001), sistemas de secagem em que se usam combustíveis líquidos ou gasosos, como gás liquefeito de petróleo (GLP) e gás natural (GN), oferece vantagens, como simplicidade de operação e excelente controle de temperatura, favorecendo a automação da secagem.

Por outro lado, a segurança alimentar está assumindo destacada importância atualmente nas relações de mercado de grãos. Os materiais orgânicos apresentam combustão difícil e incompleta, liberando grande quantidade de fuligem, fumaça e produtos químicos, alguns comprovadamente nocivos à saúde humana, destacando-se o alcatrão. Por vezes, ocorre impregnação desses contaminantes no grão, conferindo-lhe cheiro e paladar desagradáveis. Em razão disso, o uso de GLP na secagem de grãos, resulta em menor contaminação de grãos (HUTT; MEIERING; OELSCHLAGER, 1978) Devido à ausência de enxofre nos gases de combustão, que é corrosivo e ataca as estruturas do secador, ocorre um aumento da vida útil destes equipamentos (LOPES et al., 2001). 
As informações a respeito de armazenamento de grãos são limitadas no Brasil, por isso são necessários estudos que gerem conhecimentos, fundamentais para que se possa manter a qualidade dos grãos em toda a cadeia produtiva. Por estes fatores e devido às elevadas perdas que ocorrem nas etapas de póscolheita de grãos no Brasil, o trabalho objetiva, estudar o efeito de dois métodos de secagem, ar natural e GLP, sobre a qualidade físico-química de milho, armazenados a granel durante 6 meses.

\section{Material e Métodos}

Foram utilizados grãos de milho (Zea mays L.), cultivados na Estação Experimental da Universidade Federal do Rio Grande do Sul, em Eldorado do SulRS, na safra agrícola 2007/2008. As espigas foram colhidas, no mês de julho com umidade próxima a 30\%. Posteriormente os grãos foram limpos em máquina de ar e peneiras planas, para retirada de impurezas, grãos quebrados e matérias estranhas. Em seguida, divididos em 2 tratamentos de secagem $\left(\mathrm{S}_{1}\right.$ e $\left.\mathrm{S}_{2}\right)$, sendo os mesmos secos até teor de água de aproximadamente $13 \%$ em b.u. $\mathrm{S}_{1}-$ Secagem em leito fixo, em silo secador de concreto armado, com ar não aquecido, na condição ambiente, a $20 \pm 5^{\circ} \mathrm{C}$. $\mathrm{S}_{2}$ - Secagem em leito fixo, em silo secador de concreto armado, com ar natural e uso de GLP, sendo que somente era acionado o gás quando a umidade relativa do ar ultrapassasse $65 \%$, do contrário era usado somente o ar natural.

Nas secagens $\mathrm{S}_{1}$ a $\mathrm{S}_{2}$, foram utilizados fluxo de ar médio equivalente a $2,52 \mathrm{~m}^{3} \cdot \mathrm{s}^{-1}$ e altura de camada de secagem foi de um metro (50 sacos). Após a secagem os grãos ficaram armazenados nos mesmos silos secadores. Durante as operações de secagem $\left(\mathrm{S}_{1}\right.$ e $\left.\mathrm{S}_{2}\right)$, foi feito o acompanhamento da umidade com determinador dielétrico (GEOLE), previamente calibrado pelo método da estufa, sendo retiradas amostras em intervalos de tempo, para que a secagem fosse realizada até os grãos atingirem $13 \%$ de umidade. Ao final das operações e a partir daí, todas as determinações de umidade foram feitas em estufa a $105 \pm 3^{\circ} \mathrm{C}$, com circulação natural de ar (BRASIL, 2009). A temperatura e a umidade relativa, do ar ambiente foram medidas com termo higrômetro digital. A temperatura do ar de secagem foi medida com termômetro de mercúrio, com escala de $0,5^{\circ} \mathrm{C}$, sendo o mesmo posicionado em duas alturas na massa de grãos, sobre a camada superior e na camada central da massa de grãos. A velocidade do ar de secagem foi medida utilizando-se anemômetro de pás rotativas, marca TFA-Quantats-Elzeugnis - Germany, modelo 7607.01.0.00.

Durante o armazenamento foram monitoradas a temperatura e a umidade relativa do ar com termo higrômetro digital. Durante a estocagem as amostras foram retiradas com auxílio de calador ou sonda sendo coletados, cerca de $5 \mathrm{Kg}$ em cada amostragem, de cada repetição, oriundos dos 600 $\mathrm{Kg}$ que constituirão a unidade experimental piloto de cada tratamento. As análises foram realizadas em intervalos de três meses, durante seis meses, contando como tempo zero o momento após a secagem, e a partir deste momento a cada três meses ( 3 e 6 meses). Foram realizadas as seguintes análises: 1. Umidade determinada pelo método da estufa a $105 \pm 3^{\circ} \mathrm{C}$, com circulação natural de ar, por 24 horas, sendo os resultados expressos em \% de base úmida (BRASIL, 2009); 2. Peso volumétrico determinado em equipamento volumétrico Dalle Molle e balança eletrônica digital com precisão de $0,01 \mathrm{~g}$ e com capacidade de $1 / 4$ de litro, sendo necessária a conversão dos valores para peso volumétrico, expresso em kg.m ; 3. Peso de 1000 grãos, foi determinado, pela contagem de 1000 grãos e pesagem em balança eletrônica com precisão de $0,001 \mathrm{~g}$, com os resultados expressos em g. 4. Proteína bruta, o teor de proteína bruta foi determinado pelo método Kjeldahl, descrito pela A. A. C. C. (2000); 5. Extrato etéreo, a extração e a determinação do teor de gordura foram realizadas conforme o método A.O.C.S. (1996), com a utilização do aparelho Soxleht. Os resultados são expressos em percentagem; 6. Matéria mineral, o 
teor de cinzas ou matéria mineral foi determinado conforme, descrito na A.O.A.C. (1990), com incineração prévia e calcinação em mufla a 560 - $580{ }^{\circ} \mathrm{C}$, até peso constante. Os resultados são expressos em percentagem; 7. Carboidratos foram obtidos pela soma dos valores de proteína bruta, extrato etéreo e cinzas, diminuindo-se de 100, ou seja, $100-\mathrm{PB}+\mathrm{C}+\mathrm{EE}$. O delineamento experimental foi inteiramente casualizado, sendo que a análise dos resultados seguiu um esquema fatorial 2 × 3 × 3 sendo: 2 métodos de secagem $\left(\mathrm{S}_{1} \mathrm{e}\right.$ $\mathrm{S}_{2}$ ), 3 tempos de armazenamento (pós secagem (0), 3 e 6 meses) e três repetições para cada tratamento. Os dados foram interpretados por meio de análise de variância e as médias dos tratamentos comparadas aplicando-se o teste de Tukey, adotando-se o nível de $5 \%$ de probabilidade. A avaliação estatística dos resultados foi realizada por meio do Aplicativo Computacional em Estatística Aplicada à Genética - GENES (CRUZ, 2001).

\section{Resultados e Discussão}

A temperatura e a UR média do ar durante a secagem com ar natural foi de $17{ }^{\circ} \mathrm{C}$ e $72 \%$, respectivamente, sendo que a temperatura variou de 10 a $29{ }^{\circ} \mathrm{C}$ e a UR de 46 a $95 \%$ durante a secagem. A temperatura e a UR média do ar durante a secagem com ar natural / GLP foi de $22{ }^{\circ} \mathrm{C}$ e $79 \%$, respectivamente, sendo que a temperatura variou de 9 a $28^{\circ} \mathrm{C}$ e a UR de 47 a $98 \%$ durante o experimento.

Para a secagem com ar natural, a temperatura média da massa de grãos foi de $19^{\circ} \mathrm{C}$, sendo que, não ultrapassou $24{ }^{\circ} \mathrm{C}$; Para a secagem com ar natural / GLP, a temperatura média da massa de grãos foi de $20{ }^{\circ} \mathrm{C}$, sendo que, não ultrapassou $28^{\circ} \mathrm{C}$.

A temperatura e a UR, média do ar ambiente durante a secagem com ar natural foi de $15{ }^{\circ} \mathrm{C}$ e $72 \%$, respectivamente, sendo que a temperatura variou de 10 a $26{ }^{\circ} \mathrm{C}$ e a UR de 46 a $96 \%$ durante a secagem. A temperatura e a UR, média do ar ambiente durante a secagem com ar natural / GLP foi de $16{ }^{\circ} \mathrm{C}$ e $79 \%$, respectivamente, sendo que a temperatura variou de 9 a $28{ }^{\circ} \mathrm{C}$ e a UR de 47 a $98 \%$ durante o experimento.

O tempo médio de secagem com ar natural foi de 48 horas, enquanto que para a secagem com ar natural / GLP o tempo médio de secagem foi de 34 horas, demonstrando que a secagem com gás apresenta a grande vantagem de ser mais rápida do que a secagem com ar natural, resultados semelhantes aos encontrados por outros autores. Portella e Eichelberger (2001) em um trabalho de secagem com uso de GLP em três diferentes temperaturas observaram um tempo de aproximadamente 15 horas para a secagem, na temperatura mais baixa, que foi de $40{ }^{\circ} \mathrm{C}$, para uma umidade inicial de $35 \%$, com altura de camada de grãos de $0,5 \mathrm{~m}$.

\section{Parâmetros físicos e químicos de análises de qualidade e conservabilidade}

A (Tabela 1) mostra a caracterização inicial do milho que foi colhido com umidade de $31,88 \%$ b.u., apresentou peso de mil grãos de 355,28 g, peso volumétrico de $714 \mathrm{~kg} \cdot \mathrm{m}^{-3}$, proteína de 10,48\%, gordura de $4,32 \%$, cinzas de $1,38 \%$ e carboidratos de $83,82 \%$.

Nas (Tabelas 2, 3 e 4) são apresentados, respectivamente, os valores de umidade, peso de mil grãos e peso volumétrico de grãos de milho, nos tratamentos de secagem com ar natural e ar natural / GLP, durante seis meses de armazenamento a granel.

Conforme pode ser observado nas (Tabelas $1 \mathrm{e}$ 2), os grãos de milho foram colhidos com umidade de $31,88 \%$ e posteriormente secos com ar natural até atingirem umidade de $15,70 \%$ e conforme mostrado no (Gráfico 1) observa-se que as condições de temperatura e UR do ar durante a secagem levaram os grãos de milho a entrarem em equilíbrio higroscópico, devido á alta UR e baixa temperatura do ar, durante a realização da operação com ar natural, entre os dias 15 e 19 de julho (Gráfico 1). 
Tabela 1. Caracterização físico-química, para o milho safrinha, colhida no mês de julho de 2008.

\begin{tabular}{lc}
\hline Característica & Milho \\
\hline Umidade (\%b.u.) & 31,88 \\
Peso 1000 Grãos (g) & 355,28 \\
Peso Volumétrico (kg.m ${ }^{-3}$ ) & 714,47 \\
Proteínas (\%) & 10,48 \\
Gordura (\%) & 4,32 \\
Carboidratos (\%) & 83,82 \\
Cinzas (\%) & 1,38 \\
\hline
\end{tabular}

Tabela 2. Umidade em grão de milho, submetidos a dois métodos de secagem e armazenados por 6 meses ${ }^{1}$.

\begin{tabular}{lccc}
\hline \multirow{2}{*}{ Métodos de secagem } & \multicolumn{3}{c}{ Meses de armazenamento } \\
\cline { 2 - 4 } & $\mathbf{1}^{*}$ & $\mathbf{3}$ & $\mathbf{6}$ \\
\hline Secagem Ar / GLP & $13,39 \mathrm{Bb}$ & $13,87 \mathrm{Aa}$ & $12,60 \mathrm{BCa}$ \\
Secagem Ar Natural & $15,70 \mathrm{Aa}$ & $13,51 \mathrm{Ba}$ & $12,82 \mathrm{BCa}$ \\
\hline
\end{tabular}

${ }^{1}$ Médias aritméticas simples de três repetições, expressas em percentagem, em base úmida. Quando acompanhadas respectivamente, por distintas letras maiúsculas, na mesma linha e minúsculas, na mesma coluna, diferem significativamente entre si, a 5\% de probabilidade pelo teste de Tukey. * Milho armazenado após a secagem dos grãos.

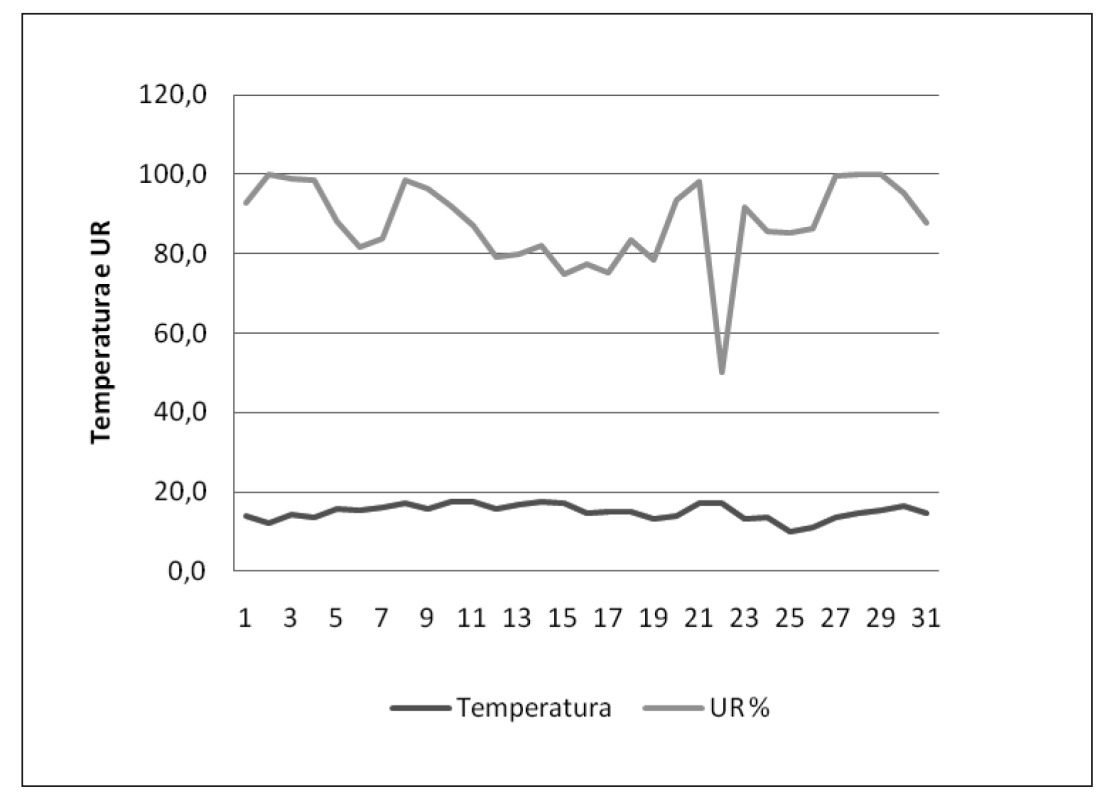

Gráfico 1. Condições de temperatura do $\operatorname{ar}\left({ }^{\circ} \mathrm{C}\right)$ e UR \% no mês de julho de 2009 , durante a realização da secagem dos grãos de milho.

Deve-se tomar o cuidado de armazenar grãos nesta condição de umidade, aerar em intervalos de 3 a 4 dias este grãos para que não sofram ataque de pragas (insetos e fungos). Aos três meses de armazenamento, após aumento da temperatura do ar, foram secos até $13,87 \%$ e aos seis meses de armazenamento apresentaram umidade de 12,60\%, variação normal da umidade de equilíbrio em função doaumento datemperaturadurante oarmazenamento. O comportamento higroscópico dos grãos no armazenamento, expresso através da variação da umidade, em associação com as alterações térmicas, 
é fundamental para a conservabilidade do produto e o manejo do sistema de armazenamento. Aumentos graduais de umidade e temperatura da massa, em função de diferentes volumes estáticos de grãos, sob certas condições de armazenamento, originam um conjunto de processos físico-químicos específicos e acumulativos na deterioração dos grãos, conhecidos como efeito de massa, o qual está estreitamente correlacionado com o desenvolvimento e a sucessão microbiana e de pragas durante a estocagem (MUIR, 1973; SALUNKHE; CHAVAN; KADAN, 1985; DIONELLO, 2000). Os grãos que foram secos com ar natural e GLP foram submetidos a temperaturas do ar de secagem maiores, visto que o gás aquece o ar e reduz a UR, atingindo o equilíbrio higroscópico em umidades menores, estes grãos foram secos até valores $13,39 \%$ e se mantendo durante o armazenamento, com variações normais durante os seis meses. Entre os tratamentos só existiu diferenças significativas no início do experimento em função do equilíbrio higroscópico dos grãos ocorrer, visto que a temperatura do ar de secagem quando se utiliza ar natural é dependente das condições climáticas, principalmente temperatura e umidade relativa. Resultados semelhantes aos encontrados por Dionello (2000), onde trabalhando com armazenamento de milho observou tendência ao equilíbrio higroscópico dos grãos de milho com umidades entre 12 e $13 \%$ ao final de 6 meses de armazenamento.

Os resultados do peso de 1000 grãos apresentados na (Tabela 3) mostram que existiu uma perda significativa dos três para os seis meses de armazenamento, em ambos os tratamentos. Também podemos observar que não existiram diferenças significativas entre os tratamentos em cada tempo de avaliação. Ao final dos seis meses de armazenamento as perdas foram iguais estatisticamente, para os grãos de milho secos com ar natural / GLP, correspondendo a 9,98 e $10,26 \%$, respectivamente. Os índices observados mostram as perdas quantitativas totais, resultantes dos processos de deterioração dos grãos, devido ao seu metabolismo intrínseco, à atividade microbiana e a de pragas associadas (CALDASSO, 1998). As menores variações correspondem aos melhores parâmetros conservativos da massa de grãos durante o armazenamento (PUZZI, 1986; ELIAS et al., 1994; ELIAS, 1998; DIONELLO, 2000).

Tabela 3. Peso de 1000 grãos (g), de milho, submetidos a dois métodos de secagem e armazenados por 6 meses ${ }^{1}$.

\begin{tabular}{lccc}
\hline \multirow{2}{*}{ Métodos de secagem } & \multicolumn{3}{c}{ Meses de armazenamento } \\
\cline { 2 - 4 } & $\mathbf{1}^{*}$ & $\mathbf{3}$ & $\mathbf{6}$ \\
\hline Secagem Ar / GLP & $300,78 \mathrm{Aa}$ & $293,48 \mathrm{Aa}$ & $270,75 \mathrm{Ba}$ \\
Secagem Ar Natural & $320,45 \mathrm{Aa}$ & $303,43 \mathrm{Aa}$ & $287,57 \mathrm{Ba}$ \\
\hline
\end{tabular}

${ }^{1}$ Médias aritméticas simples de três repetições, expressas em percentagem, em base úmida. Quando acompanhadas respectivamente, por distintas letras maiúsculas, na mesma linha e minúsculas, na mesma coluna, diferem significativamente entre si, a $5 \%$ de probabilidade pelo teste de Tukey. * Milho armazenado após a secagem dos grãos.

Os resultados do peso volumétrico apresentados na Tabela 4 mostram que existiu uma perda significativa ao longo dos seis meses de armazenamento, em ambos os tratamentos, sendo que no tratamento secagem ar natural / GLP, os grãos apresentaram uma maior perda de peso volumétrico em comparação com os grãos que foram secos com ar natural, sendo de $22,6 \%$ e de
20,98\%, respectivamente. Mostrando que os grãos que foram secos com ar natural, apresentaram maior conservação ao final do período de armazenamento, porém os grãos secos com ar natural apresentaram valores mais baixos de peso volumétrico, em comparação com aqueles secos com ar natural / GLP. Assim como o peso de 1000 grãos (Tabela 3), o peso volumétrico está intimamente relacionado 
com a integridade biológica dos grãos. Sua redução, durante $o$ armazenamento, significa consumo de nutrientes, geralmente em conseqüência do metabolismo de organismos associados e dos próprios grãos (ROMBALDI, 1988; ELIAS et al., 1997; ELIAS, 1998; DIONELLO, 2000; ELIAS, 2008).

Nas tabelas 05, 06, 07 e 08 são apresentados, respectivamente, os valores de proteína bruta, extrato etéreo, cinzas ou material mineral e carboidratos de grãos de milho, nos tratamentos de secagem com ar natural e ar natural / GLP, durante seis meses de armazenamento a granel.

Os resultados da análise de proteína bruta apresentados na Tabela 5 mostram que as amostras que foram secas com ar natural apresentaram uma maior perda de proteína bruta em comparação com as amostras que foram secas com ar natural / GLP, sendo de 4,08 e 1,94\%, respectivamente. As perdas de proteínas ocorrem em função das características químicas intrínsecas de degradação e/ou de requerimento dos seus constituintes, frente aos fatores físico-químicos e biológicos das condições de armazenamento. $\mathrm{O}$ tratamento que foi seco com ar natural / GLP, não apresentou perdas significativas ao longo do armazenamento. Com exceção do período inicial de armazenamento, durante os dois outros períodos de armazenamento (3 e 6 meses) os dois tratamentos foram estatisticamente iguais. Esta degradação de proteína está relacionada com o teor de água dos grãos, o tratamento secagem com ar natural até os três meses de armazenamento apresentou umidade (Tabela 2) maior que os grãos que foram secos com GLP, apresentando uma maior respiração e maior consumo de reservas, levando a uma maior perda dos constituintes químicos (Tabelas 5, 6 e 8). Desde a formação, as proteínas dos grãos de milho sofrem reações como hidrólise, descarboxilização, desaminação e complexação com outros componentes químicos dos próprios grãos, as quais continuam após a colheita. Pela desaminação dos aminoácidos há formação de ácidos orgânicos e compostos amoniacais. Pela descarboxilação são originadas, principalmente, aminas, características do processo de putrefação dos grãos, como os odores fortes e desagradáveis. Da complexação com açúcares redutores ocorre o escurecimento dos grãos, com a conseqüente diminuição do teor de nitrogênio protéico e o aumento do conteúdo de nitrogênio não protéico (POMERANZ, 1974; ABRAMSON; SINHA; MILLS, 1980).

Tabela 5. Análise de proteínas de grãos de milho (\%), submetidos a dois métodos de secagem e armazenados por 6 meses ${ }^{1}$.

\begin{tabular}{lccc}
\hline \multirow{2}{*}{ Métodos de secagem } & \multicolumn{3}{c}{ Meses de armazenamento } \\
\cline { 2 - 4 } & $\mathbf{1 *}$ & $\mathbf{3}$ & $\mathbf{6}$ \\
\hline Secagem Ar / GLP & $9,79 \mathrm{Ab}$ & $9,71 \mathrm{Aa}$ & $9,60 \mathrm{Aa}$ \\
Secagem Ar Natural & $10,27 \mathrm{Aa}$ & $9,92 \mathrm{ABa}$ & $9,85 \mathrm{Ba}$ \\
\hline
\end{tabular}

${ }^{1}$ Médias aritméticas simples de três repetições, expressas em percentagem, em base úmida. Quando acompanhadas respectivamente, por distintas letras maiúsculas, na mesma linha e minúsculas, na mesma coluna, diferem significativamente entre si, a $5 \%$ de probabilidade pelo teste de Tukey. * Milho armazenado após a secagem dos grãos.

Os resultados da análise de extrato etéreo apresentados na Tabela 6 mostram que houve perdas significativas nos grãos armazenados que foram secos com ar natural, enquanto que no tratamento com ar natural / GLP, os grãos não apresentaram alterações estatísticas durante os seis meses de armazenamento. As perdas foram de $18,36 \%$ para a secagem com ar natural e de
$8,37 \%$ para a secagem com ar natural / GLP. Entre os tratamentos em cada tempo de armazenamento as perdas foram iguais estatisticamente. Conforme Pomeranz (1974), Elias et al. (1994), Elias et al. (1997) e Elias, (2008), os lipídeos caracterizam a fração constituinte mais suscetível à deterioração dos grãos de milho durante o armazenamento, devido à redução do seu conteúdo total e/ou pela 
suscetibilidade a alterações estruturais. As ações das lipases, galactolipases e fosfolipases dos próprios grãos e das produzidas pela microflora associada contribuem para o rompimento das ligações éster dos glicerídeos neutros e dos fosfolipídeos, aumentando o teor de ácidos graxos livres. Christensen e Kaufman (1965), citados por Krabbe
(1995), relatam que os fungos produzem lipases, que degradam a gordura dos cereais a ácidos graxos livres, os quais são usados como fonte de energia para eles mesmos, no seu próprio metabolismo. Teor de água mais elevado também levou a uma maior degradação de lipídeos no tratamento secagem com ar natural, durante o armazenamento.

Tabela 6. Análise de extrato etéreo de grãos de milho (\%), submetidos a dois métodos de secagem e armazenados por 6 meses ${ }^{1}$.

\begin{tabular}{lccc}
\hline \multirow{2}{*}{ Métodos de secagem } & \multicolumn{3}{c}{ Meses de armazenamento } \\
\cline { 2 - 4 } & $\mathbf{1}^{*}$ & $\mathbf{3}$ & $\mathbf{6}$ \\
\hline Secagem Ar / GLP & $4,06 \mathrm{Aa}$ & $3,92 \mathrm{Aa}$ & $3,72 \mathrm{Aa}$ \\
Secagem Ar Natural & $4,14 \mathrm{Aa}$ & $3,58 \mathrm{BCa}$ & $3,38 \mathrm{Ca}$ \\
\hline
\end{tabular}

${ }^{1}$ Médias aritméticas simples de três repetições, expressas em percentagem, em base úmida. Quando acompanhadas respectivamente, por distintas letras maiúsculas, na mesma linha e minúsculas, na mesma coluna, diferem significativamente entre si, a $5 \%$ de probabilidade pelo teste de Tukey. * Milho armazenado após a secagem dos grãos.

Os resultados da análise de cinzas ou constituintes minerais, constantes da Tabela 7, não mostram diferenças significativas tanto entre os dois métodos de secagem, como entre os períodos de armazenamento. Segundo Salunkhe, Chavan e Kadan (1985), o conteúdo mineral, representado pelo teor de cinzas, é, dos constituintes químicos dos grãos de milho, a fração que apresenta as menores variações no seu conteúdo total durante o armazenamento. A atividade metabólica dos grãos e dos microrganismos associados consome a matéria orgânica, metabolizando-a até $\mathrm{CO}_{2}$, água e outros produtos, com liberação de calor, podendo transformar estruturalmente a composição mineral sem alterar o seu conteúdo total. Dessa forma, a determinação do teor de cinzas assume valores proporcionalmente maiores à medida que a matéria orgânica é consumida. Aos menores incrementos proporcionais aparentes de minerais correspondem os melhores efeitos conservativos relativos (FORLIN, 1991; ELIAS, 1998; DIONELLO, 2000; ELIAS, 2008).

Tabela 7. Análise de matéria mineral ou cinzas de grãos de milho (\%), submetidos a dois métodos de secagem e armazenados por 6 meses ${ }^{1}$.

\begin{tabular}{lccc}
\hline \multirow{2}{*}{ Métodos de secagem } & \multicolumn{3}{c}{ Meses de armazenamento } \\
\cline { 2 - 4 } & $\mathbf{1}^{*}$ & $\mathbf{3}$ & $\mathbf{6}$ \\
\hline Secagem Ar / GLP & $1,26 \mathrm{Aa}$ & $1,32 \mathrm{Aa}$ & $1,37 \mathrm{Aa}$ \\
Secagem Ar Natural & $1,28 \mathrm{Aa}$ & $1,44 \mathrm{Aa}$ & $1,47 \mathrm{Aa}$ \\
\hline
\end{tabular}

${ }^{1}$ Médias aritméticas simples de três repetições, expressas em percentagem, em base úmida. Quando acompanhadas respectivamente, por distintas letras maiúsculas, na mesma linha e minúsculas, na mesma coluna, diferem significativamente entre si, a 5\% de probabilidade pelo teste de Tukey. * Milho armazenado após a secagem dos grãos.

Os resultados da análise de carboidratos, constantes da (Tabela 8), mostram que houve uma variação significativa ao longo do tempo de armazenamento, dos 3 para os 6 meses, apenas para aqueles grãos que foram submetidos a secagem com ar natural, não diferindo também em cada tempo de armazenamento. $\mathrm{O}$ aumento observado trata-se de aumento virtual, aparente ou relativo, uma vez que decorre da diminuição entre as frações proteína e extrato etéreo durante o armazenamento. 
Tabela 8. Análise de carboidratos de grãos de milho (\%), submetidos a dois métodos de secagem e armazenados por 6 meses ${ }^{1}$.

\begin{tabular}{lccc}
\hline \multirow{2}{*}{ Métodos de secagem } & \multicolumn{3}{c}{ Meses de armazenamento } \\
\cline { 2 - 4 } & $\mathbf{1}^{*}$ & $\mathbf{3}$ & $\mathbf{6}$ \\
\hline Secagem Ar / GLP & $84,89 \mathrm{Aa}$ & $85,05 \mathrm{Aa}, 31 \mathrm{Aa}$ \\
Secagem Ar Natural & $84,31 \mathrm{Ba}$ & $85,06 \mathrm{ABa}$ & $85,30 \mathrm{Aa}$ \\
\hline
\end{tabular}

${ }^{1}$ Médias aritméticas simples de três repetições, expressas em percentagem, em base úmida. Quando acompanhadas respectivamente, por distintas letras maiúsculas, na mesma linha e minúsculas, na mesma coluna, diferem significativamente entre si, a $5 \%$ de probabilidade pelo teste de Tukey. * Milho armazenado após a secagem dos grãos.

Os carboidratos são constituintes dos grãos diretamente consumidos pelo próprio metabolismo e por microrganismos associados, refletindo-se em decréscimo real do seu conteúdo total durante o armazenamento (SALUNKHE; CHAVAN; KADAN, 1985). A maior proporção relativa de carboidratos dos grãos de milho, as maiores perdas das frações proteína e extrato etéreo, a forma de expressão percentual e o critério de determinação proximal conduzem ao comportamento observado, onde as menores variações estão associadas aos melhores efeitos conservativos desses compostos nos grãos durante o armazenamento (FORLIN, 1991; CALDASSO, 1998; DIONELLO, 2000).

\section{Conclusões}

1. A secagem com ar natural / GLP foi mais rápida do que a secagem com ar natural nas condições do estudo;

2. Em condições de alta UR e temperaturas baixas a secagem com ar natural deve ser realizada com cuidados, devido ao equilíbrio higroscópico dos grãos;

3. Os dois métodos de secagem são viáveis em termos de qualidade, porém as perdas de proteína bruta, extrato etéreo e carboidratos, foram maiores durante os seis meses de armazenamento, nos grãos secos com ar natural;

4. A secagem com ar natural pode ser uma excelente alternativa para secagem de grãos por pequenos produtores.

\section{Agradecimentos}

Ao CNPq, UFRGS e a SHV Gás Brasil, pelo auxílio para realização do trabalho.

\section{Referências}

AMERICAN ASSOCIATION OF CEREAL CHEMISTS - AACC. Approved methods AACC, $10^{\text {th }}$ ed. St. Paul, MN, 2000.

ASSOCIATION OF OFFICIAL ANALYTICAL CHEMISTRY - AOAC. Official methods of analysis of the Association of Official Analytical Chemistry. 16. ed. Arlington: Washington, v. I, II, 1990.

AMERICAN OIL CHEMISTS SOCIETY - AOCS. Official and Tentatives Methods of American Oil Chemestry Society. New York: D.C. 1996.

ABRAMSON, D.; SINHA, R. N.; MILLS, J. T. Mycotoxin and odor formacion in moist cereal grain during granary storage. Cereal Chemestry St. Paul: A.A.C.C., 1980.

BRASIL. Ministério da Agricultura, Pecuária e Abasteciemtno (MAPA) - DAS. Regras para análise de sementes. Brasília: Assessoria de Comunicação Social/ ACS/MAPA., 2009. 399 p.

CALDASSO, L. H. Ácidos orgânicos e sistemas de armazenamento na conservação de milho em pequena escala. 1998. Dissertação (Mestrado no Programa de Pós-Graduação em Ciências e Tecnologia de Alimentos) - Departamento de Ciências e Tecnologia de Alimentos. Universidade Federal de Pelotas, Pelotas.

COMPANHIA NACIONAL DE ABASTECIMENTO CONAB. Noticias. Disponível em: <http://www.conab. gov.br/conabweb/>. Acesso em: 25 set. 2009.

CRUZ, C. D. Programa GENES (Versão Windows). Aplicativo computacional em genética e estatística. Viçosa, MG:UFV, 2001, 648 p. 
DIONELLO, R. G. Método de secagem e sistema de armazenamento na qualidade dos grãos e na ocorrência de micotoxinas em milho. 2000. Dissertação (Mestrado no Programa de Pós-Graduação em Ciências e Tecnologia de Alimentos) - Departamento de Ciências e Tecnologia de Alimentos. Universidade Federal de Pelotas, Pelotas.

ELIAS, M. C. Manejo tecnológico da secagem e do armazenamento de grãos. Pelotas: Ed. Santa Cruz, 2008. $457 \mathrm{p}$.

Tempo de espera para secagem e qualidade de arroz para semente e uso industrial. 1998. Tese (Doutorado em Tecnologia de Sementes) - Departamento de Ciência e Tecnologia de Sementes. Universidade Federal de Pelotas. Faculdade de Agronomia Eliseu Maciel, Pelotas.

ELIAS, M. C.; ROMBALDI, C. V.; DIAS, A. R. G.; SILVA, J. A.; NORA, L. Secagem, armazenamento e conservação de grãos na propriedade rural. Pólo de modernização tecnológica em alimentos da Região Sul do Rio Grande do Sul. Pelotas: UFPEL/FAEM/DCTA, 1994. $17 \mathrm{p}$.

Secagem e armazenamento de grãos: sistemas, métodos e processos. pólo de modernização tecnológica em alimentos da Região Sul do Rio Grande do Sul. Pelotas: UFPEL/FAEM/DCTA, 1997. 52 p.

FAO - Food and Agriculture Organization of the United Nations Better information sharing could reduce postharvest food losses - New database launched. FAO. Rome. Disponível em: <www.fao.org/es/>. Acesso em: 05 out. 2009.

FORLIN, F. J. Efeito da hermeticidade e da aplicação de ácidos orgânicos no armazenamento de grãos de sorgo (Sorghum bicolor, L.). Pelotas: Universidade Federal de Pelotas, 1991. Dissertação (Mestrado em Ciência e Tecnologia Agroindustrial) - Faculdade de Agronomia Eliseu Maciel. Universidade Federal de Pelotas, Pelotas.

HUTT, W.; MEIERING, A.; OELSCHLAGER, W. Grain contamination in drying with direct heating. Canadian Agricultural Engineering, Canadá, v. 20, n. 2, p. 103107, dec. 1978.

KRABBE, E. L. Efeitos do desenvolvimento fúngico em grãos de milho durante o armazenamento e do uso de ácido propiônico sobre as características nutricionais e o desempenho de frangos de corte. 1995. Dissertação (Mestrado em Zootecnia) - Departamento de Zootecnia.
Universidade Federal do Rio Grande do Sul. Faculdade de Agronomia, Porto Alegre.

LOPES, R. P.; SOBRINHO, J. C.; SILVA, J. S.; SILVA, J. N. Fontes de energia para secagem de café. Engenharia na agricultura. Viçosa, MG, 2001. 26 p. (Boletim Técnico, 3).

LORINI, I.; MIIKE, L. H.; SCUSSEL, V. M. Armazenagem de grãos. Campinas: Instituto Biogeneziz, 2002. v. 1, 1000 p.

MUIR, W. E. Temperature and moisture in grain storages. In: SINHA, R. N.; MUIR, W. E. (Ed.). Grain storage part of a system. Washington: AVI Publishing, 1973. p. 49-70.

POMERANZ, Y. Biochemical, functional and nutritive changes during storage. In: CRISTENSEM, C. M. (Ed.). Storage of cereal grains and their products. St. Paul. 1974. p. 56-114.

PORTELLA, J. A.; EICHELBERGER, L. Secagem de grãos. Passo Fundo: Embrapa Trigo, 2001. 194 p.

PROGRAMA MULTINSTITUCIONAL DE DIFUSÃO DE TECNOLOGIAEM MILHO DO RS. Recomendações técnicas para a cultura do milho no Rio Grande do Sul. Programa multinstitucional de difusão de tecnologia em milho. Porto Alegre: FEPAGRO, EMATER/RS, FECOTRIGO, 1996. (Boletim Técnico, 3).

PUZZI, D. Armazenamento e abastecimento de grãos. Campinas: Instituto Campineiro de Ensino Agrícola, 1986. $603 \mathrm{p}$.

ROMBALDI, C. V. Condições de secagem e tempo de armazenamento na qualidade industrial do arroz. 1988. Dissertação (Mestrado em Ciências e Tecnologia de Alimentos) - Departamento de Ciências e Tecnologia de Alimentos. Universidade Federal de Pelotas, Pelotas.

SALUNKHE, D. K.; CHAVAN, J. K.; KADAN, S. S. Maize. Postharvest biotechnology of cereals. Boca Raton: CRC, 1985. p. 127-146.

SARTORI, J. A. Qualidade dos grãos de milho após $o$ processo de secagem. 2001. Tese (Dissertação de Mestrado em Engenharia Agrícola) - Departamento de Engenharia Agrícola. Universidade Estadual de Campinas. Faculdade de Engenharia Agrícola, Campinas.

WEBER, E. A. Armazenagem agrícola. 2. ed. Porto Alegre: Kepler Weber, 1998. 400 p. 